\title{
Differentiation of Inotropic Action from Chronotropic Action of Sympathetic Agents in Cultured Cells of Chick Embryonic Ventricles
}

\author{
Hiroko Toyota and Moto Matsumura \\ Department of Physiology, Kawasaki Medical School, Kurashiki, 701-01 Japan
}

\begin{abstract}
The rate of the spontaneous activity of cultured cells from the chick embryonic ventricle was only slightly increased by norepinephrine (NE) or epinephrine (EP), even if it was applied close to the cell. On the other hand, the amplitude of contraction, measured from the shortening of the diameter of the cell aggregate, was clearly augmented by up to $50 \%$. Intracellularly injected cAMP also potentiated contraction. Namely, NE, EP, or cAMP showed positive inotropic action but slight chronotropic action on cultured ventricle cells. NE produced an increase in the action potential amplitude, shortening of action potential, and slight hyperpolarization in 17- to 19-day-old but not in 7- to 9-day-old embryo. If NE was applied to the cells whose plateau potential was inhibited by the previous treatment with nifedipine, NE recovered the plateau level to the control. Iontophoretically injected cAMP also recovered the plateau level once it had been inhibited by nifedipine or verapamil. In some cells, the membrane was transiently depolarized after the end of injection and turned back to the control level. This transient depolarization took place spontaneously again. It was suggested that the $\mathrm{Ca}^{2+}$-induced $\mathrm{Ca}^{2+}$ release mechanism from the sarcoplasmic reticulum was involved in the cyclic depolarization.
\end{abstract}

Key words: cultured heart cells, chick embryo, norepinephrine, epinephrine, iontophoresis of cAMP.

The effects of norepinephrine (NE) and epinephrine (EP) on the spontaneous beating rates of cultured cardiac cells have already been investigated by several authors. But, these previous results are not always consistent with each other. SPERELAKIS and LeHMKUHL (1965) first reported that the cultured embryonic ventricular cells were insensitive to NE, but ERTEL et al. (1971) demonstrated the positive chronotropic action of the adrenergic agents. GoshimA (1976) found that the cultured heart cells of the embryonic mouse were also insensitive to NE whereas

Received for publication May 30, 1988 
those of the newborn mouse responded to NE, similar to the adult heart cells. SHIGENOBU et al. (1980) described the transient increase in spontaneous beating rate by NE but sustained decrease by dibutyryl cyclic AMP (DBcAMP). According to HERMSMEYER and RoBINSON (1977), the cells were sensitive to the autonomic agents if they were applied close to the single cell which was beating spontaneously. They explained that the desensitization of the cells was the principal reason for low effectiveness of NE applied to the bulk solution of culture medium. Furthermore, it was shown that newborn rat cells cultured from sinoatrial node were 100 or 1,000 times as sensitive as those from ventricle (MARVIN et al., 1984). The effect of the sympathetic agents on contraction was only briefly reported by SPERELAKIS (1972, p. 32), and has not been further investigated.

The present work was carried out to investigate the effects of NE or EP on contraction, measured from the edge movement of a cell aggregate (CLUSIN, 1981). The effect of intracellularly injected cAMP was also examined. Spontaneous action potentials were recorded to find the changes in plateau under the influence of the sympathetic agents, because it has been known that NE and EP increase slow inward current in adult cardiac cells (REUTER, 1974; REUTER and SCHOLTZ, 1977; KASS and Wiegers, 1982; Reuter et al., 1983). It was demonstrated that the ventricular cells exhibited the lasting sensitivity to NE or EP in maintaining the augmented contraction.

\section{METHODS}

The procedures for tissue culture of chick embryonic cells and for recording the electrical and mechanical activities were described in the previous paper (TOYOTA and Matsumura, 1989). Usually, 7- to 9-day-old embryos were used, because the cells younger than 5 days old were easily damaged during microelectrode insertion. Seventeen- to 19-day-old cells were also used to determine the developmental changes in sensitivity to the sympathetic agents. Norepinephrine hydrochloride, $l$ epinephrine bitartrate, Na salt of DBcAMP, and Na salt of cAMP were supplied from Sigma Chem. Co. NE, EP, and DBcAMP were applied to the cells by two methods. In the steady chamber method, the drug was dissolved in distilled water at the concentration of $10^{-4}-10^{-5} \mathrm{M}$ and $0.02 \mathrm{ml}$ of the solution was dropped into the medium of $2 \mathrm{ml}$, distant from the cells from which membrane potential was recorded. In the ejection method, $10^{-4} \mathrm{M}$ solution was poured into a thin glass pipette and was ejected close to the cell aggregate at the rate of $0.5 \mu \mathrm{l} / \mathrm{s}$ by hydrostatic pressure from a syringe. During the period for the ejection to be off, the negative pressure was applied to prevent the leakage of the test solution. The second method prevented the cells from being desensitized to NE or EP and was convenient for observation of the reversibility of drug action.

Injection of cAMP was performed following the method of TSIEN et al. (1972). The intracellular glass microelectrode was filled with $1.5 \mathrm{M} \mathrm{Na-cAMP}$ and was inserted into one of the cells within an aggregate. The negative current of 
$1-5 \times 10^{-8} \mathrm{~A}$ was passed intermittently with a 2 -s injection period and an intervening 1-s interval with total duration for 3-8 min. This cAMP electrode was connected either to current source or to an amplifier through an electromagnetic switch and it was provided both to injection and to the membrane potential measurement. Thus, the membrane potential was recorded from the cell into which cAMP was injected. For control, $\mathrm{Na}$ salt of adenosine 5'-monophosphate (Sigma Chem. Co.) was injected with the same procedure as cAMP injection, as was described in the paper of TSIEN et al. (1972). In early experiments, the membrane potential was simultaneously recorded during cAMP injection with a double-barreled electrode. The results showed that the membrane potential was shifted by more than $50 \mathrm{mV}$ or even $100 \mathrm{mV}$ towards more negative potential, but the spontaneous activities were not completely inhibited meanwhile. At the time of the end of current pass the action potential was generated, namely, anode break excitation. The disadvantage in double-barreled electrode was that the leakage of injection current through barreled wall changed the tip potential of the $3 \mathrm{M} \mathrm{KCl}$ electrode and distorted measurement of the injection current.

VoGel and SPERELAKIS (1981) obtained the value of 0.024 for the transport number of cAMP in free solution. When electrophoretic current of $1 \times 10^{-8} \mathrm{~A}$ was passed for $60 \mathrm{~s}$ then the total amount of injected cAMP was $1.5 \times 10^{-13} \mathrm{~mol}$. The common size of the cell aggregate was assumed to be a disk of $0.3-0.5 \mathrm{~mm}$ in diameter and $0.1 \mathrm{~mm}$ in thickness, so the concentration of injected cAMP would be $20-8 \times 10^{-6} \mathrm{M}$. This calculation came from the assumptions that the injected cAMP was not dissociated and that it was distributed uniformly within the cell aggregate. It was probable that injected cAMP diffused to neighboring cells within a cell aggregate through close junctions, as was proved for adult Purkinje fibers (TsIEN and Weingart, 1976). Thereofore, several minutes of injection time would be enough to obtain the effective concentration of the order of $10^{-6} \mathrm{M}$ (FABIATO and Fabiato, 1975, 1978; Flitney and SinGH, 1980).

\section{RESULTS}

\section{Rhythm and shape of spontaneous action potentials in NE and EP solutions}

The spontaneous activity of 7-day-old embryonic cells continued to beat at 72$116 / \mathrm{min}$ at $33{ }^{\circ} \mathrm{C}$. In about $80 \%$ of these young cells, the action potential had a low amplitude, a smooth plateau, and a distinct pacemaker potential. On the other hand, most of 17- to 19-day-old embryonic cells showed low beating rates of 60 $92 /$ min, with the action potentials having a deep diastolic potential, a large overshoot, a marked plateau but a small pacemaker potential. These differences in action potential parameters between 7- to 9-day-old cells and 17- to 19-day-old ones are presented in Table 1. The irregularly beating cells are excluded from the results.

$\mathrm{NE}$ changed the rate of the spontaneous activity only slightly. Figure 1 shows a train of action potentials when NE was applied following the ejection method. The rate of the spontaneous activity was $76 / \mathrm{min}$ in control and it was increased to 
Table 1. Rhythm and shape of action potentials as influenced by NE and EP.

\begin{tabular}{|c|c|c|c|c|c|}
\hline $\begin{array}{l}\text { Age } \\
\text { (day) }\end{array}$ & $\begin{array}{c}\text { Conc. of } \\
\text { NE or EP } \\
\left(10^{-6} \mathrm{M}\right)\end{array}$ & $\begin{array}{c}\text { Rhythm } \\
\left(\text { min }^{-1}\right) \\
\text { control test }^{1 \prime}\end{array}$ & $\begin{array}{l}\text { Peak action } \\
\text { potential } \\
(\mathrm{mV}) \\
\text { control test }\end{array}$ & $\begin{array}{l}\text { Time for } 1 / 4 \\
\text { repolarization } \\
(\mathrm{ms}) \\
\text { control test }\end{array}$ & $\begin{array}{c}\text { Time for } 3 / 4 \\
\text { repolarization } \\
(\mathrm{ms}) \\
\text { control test }\end{array}$ \\
\hline \multirow[t]{7}{*}{$7-9$} & $2.0-5.0$ & 83 & 96 & 88 & 160 \\
\hline & $n=5$ & 88 & 100 & 94 & 164 \\
\hline & $20-30$ & 85 & 90 & 83 & 149 \\
\hline & $n=3$ & 89 & 93 & 87 & 153 \\
\hline & Ejection $^{2)}$ & 102 & 92 & 79 & 145 \\
\hline & $n=7$ & 109 & 94 & 79 & 140 \\
\hline & $\begin{array}{l}\text { Total of }{ }^{3)} \\
\text { the above }\end{array}$ & $\begin{array}{l}92 \pm 4.8 \\
98 \pm 5.8\end{array}$ & $\begin{array}{l}93 \pm 2.3 \\
95 \pm 1.9\end{array}$ & $\begin{array}{l}83 \pm 2.9 \\
85 \pm 3.5\end{array}$ & $\begin{array}{l}151 \pm 6.1 \\
151 \pm 7.1\end{array}$ \\
\hline \multirow[t]{2}{*}{$*$} & $2.6-5.2$ & 82 & 90 & 87 & 152 \\
\hline & $n=3$ & 86 & 94 & 87 & 150 \\
\hline \multirow[t]{7}{*}{$17-19$} & $1.0-2.3$ & 84 & 101 & 138 & 229 \\
\hline & $n=5$ & 85 & 108 & 141 & 215 \\
\hline & 23 & 68 & 114 & 150 & 240 \\
\hline & $n=1$ & 70 & 114 & 150 & 205 \\
\hline & Ejection & 66 & 104 & 147 & 241 \\
\hline & $n=6$ & 70 & 106 & 148 & 216 \\
\hline & $\begin{array}{l}\text { Total of } \\
\text { the above }\end{array}$ & $\begin{array}{r}74 \pm 3.8 \\
76 \pm 3.3\end{array}$ & $\begin{array}{c}104 \pm 2.3 \\
107 \pm 1.5\end{array}$ & $\begin{array}{c}143 \pm 2.2 \\
145 \pm 2.9\end{array}$ & $\begin{array}{l}236 \pm 3.8 \\
215 \pm 5.7\end{array}$ \\
\hline
\end{tabular}

* shows the results on EP, and others on NE. 1) All of the values in NE or EP medium are obtained from the same cells as the control cells. ${ }^{2)}$ In ejection method, the concentration of NE was not determined but supposed to be less than $10^{-5} \mathrm{M}$. ${ }^{3)}$ The values are expressed as mean \pm S.E.

$85 / \min 5 \mathrm{~min}$ after starting the ejection. The transient increase in the spontaneous activity, as was reported by SHIGENOBU et al. (1980), was not observed. Rhythm and shape of action potentials in NE and EP medium is shown in Table 1. The positive chronotropic action on NE or EP was not so clearly observed whether it was applied into the culture medium by the steady chamber method or close to the cell aggregate by the ejection method. Table 1 indicates that NE increased the peak action potential, shortened duration of its tail, and shifted the diastolic potential to hyperpolarized direction in old cells but not in young ones.

If the solution of high concentration of NE was ejected close to the cell so that the concentration around the cells was temporarily more than $10^{-4} \mathrm{M}$, the maximum diastolic potential was shifted toward less negative by $10-15 \mathrm{mV}$, as illustrated in Fig. 2. The rate was increased, but it was not certain whether the increase took place as the result of $\mathrm{NE}$ action or the change in diastolic potential. After the transient 


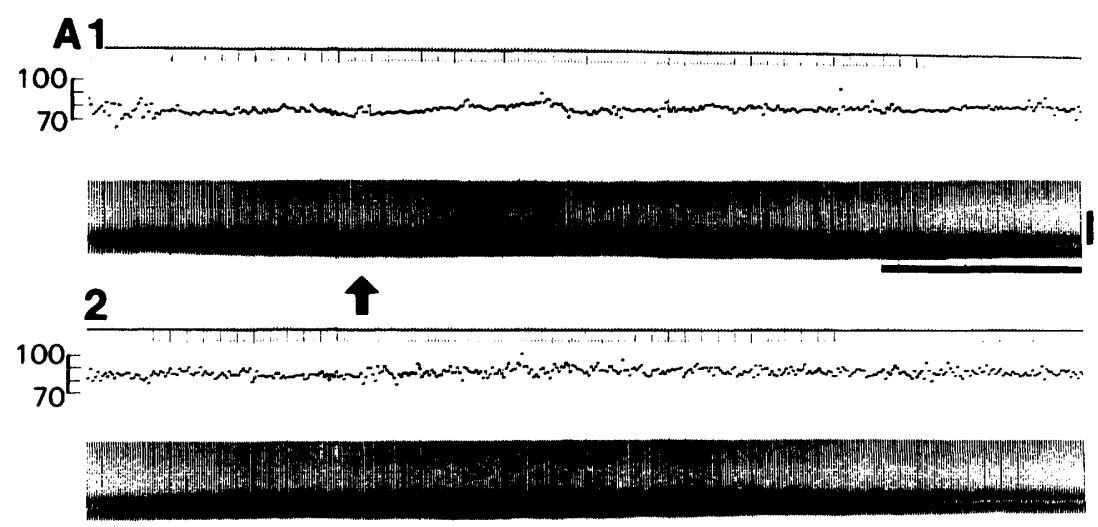

Fig. 1. Continuous recording of action potentials (lower trace) before and after application of NE. The rate of activities per minute is represented by a tachograph (upper trace). Record A1 is continued by A2. At the time indicated by an arrow, $3 \times 10^{-4} \mathrm{M}$ NE solution was applied so that the final concentration was $3 \times 10^{-6} \mathrm{M}$. 9-day-old embryo. Vertical calibration is $40 \mathrm{mV}$ and horizontal one is $1 \mathrm{~min} .33^{\circ} \mathrm{C}$.

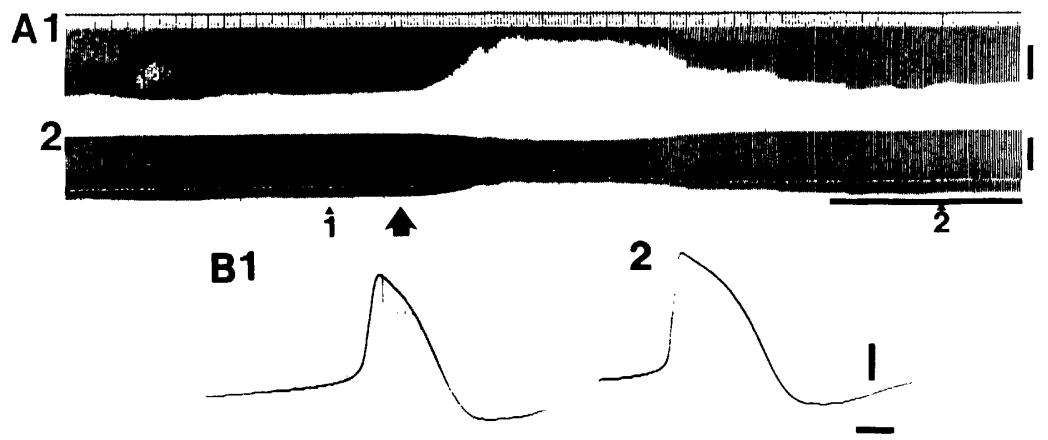

Fig. 2. A: continuous recording of action potentials (lower trace) and of diastolic potential level (upper trace). At the arrow, $3.5 \times 10^{-4} \mathrm{M} \mathrm{NE}$ was ejected close to the cell aggregate. 9-day-old embryo. Vertical calibrations are $10 \mathrm{mV}$ (upper trace) and $40 \mathrm{mV}$ (lower trace), and horizontal calibration is $1 \mathrm{~min}$. B: B1 and B2 are cathode ray oscilloscope (CRO) recordings of the action potentials marked by triangles in A. $33.5^{\circ} \mathrm{C}$.

depolarization period, as ejected NE diffused away, the maximum diastolic potential became gradually more negative than the control. The overshoot potential increased and plateau increased and lengthened (Fig. 2B), but the rate of the spontaneous activity decreased.

\section{Rhythm and shape of spontaneous action potential following cAMP injection}

To investigate whether very little effect of NE on the spontaneous rate originated in catecholamine reception mechanism or in intracellular enzymatic 

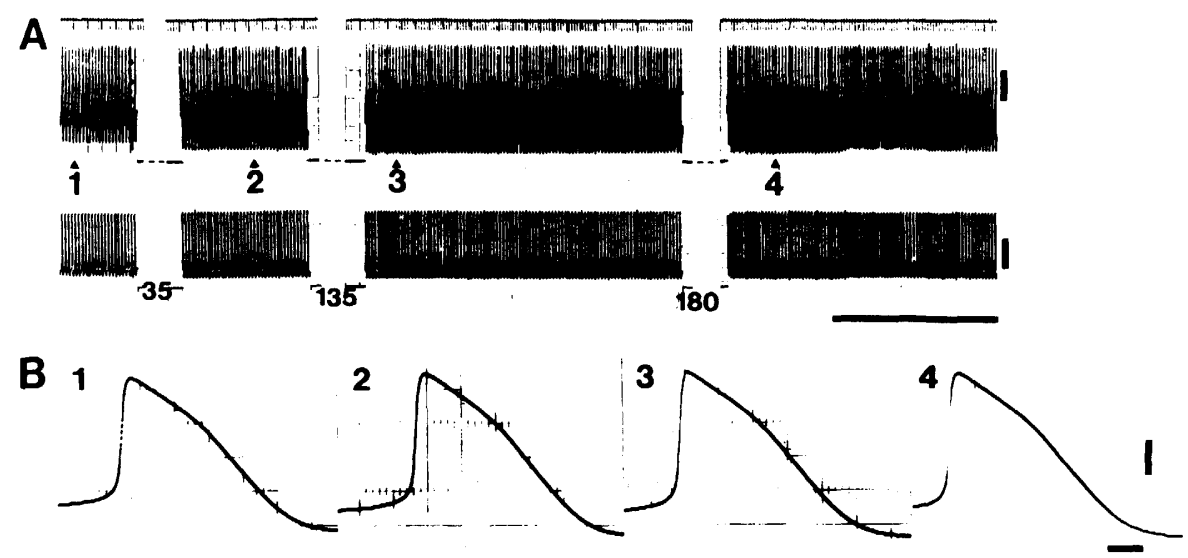

Fig. 3. A: continuous recordings of a train of action potentials (lower trace) and of diastolic action potentials (upper trace). During interrupted period of potential recording cAMP is intracellularly injected with the iontophoretic current of $2 \times 10^{-8} \mathrm{~A}$. The numbers indicate the duration of injection in seconds. Vertical calibrations are $10 \mathrm{mV}$ and $40 \mathrm{mV}$, and horizontal calibration is $1 \mathrm{~min}$. B: B1 through $\mathrm{B} 4$ are the $\mathrm{CRO}$ recordings of action potentials marked by triangles in $\mathrm{A}$. Calibrations are $20 \mathrm{mV}$ and $50 \mathrm{~ms} .10$-day-old embryo. $32^{\circ} \mathrm{C}$.

mechanism, cAMP was directly injected into the cell through the intracellular microelectrode. Figure 3 shows the membrane potential change during spontaneous activities before and after cAMP injection. The rate was $53-54 / \mathrm{min}$ throughout the experiment. Careful examination revealed that the maximum diastolic potential was shifted toward hyperpolarized direction by $3-5 \mathrm{mV}$. This hyperpolarization was small but it was certainly observed after the injection with the iontophoretic currents of $1-5 \times 10^{-8} \mathrm{~A}$ lasting for more than $5 \mathrm{~min}$, as is shown in also Fig. 4B. Addition of theophylline at $1 \mathrm{mM}$ was ineffective to modulate the effect of cAMP. The effect of theophylline at higher concentration has not yet been tested.

In 3 out of more than 20 cell aggregates, the membrane was transiently depolarized immediately after the interruption of injection current (Fig. 4). The depolarization lasted for $30 \mathrm{~s}$ and was accompanied by the increase in the rate of the spontaneous activity. The transient changes were not observed when the negative current was passed through the microelectrode filled with $2 \mathrm{M} \mathrm{K}_{3}$-citrate. Therefore, it is quite certain that the membrane potential change results from the effect of cAMP and not from an artifact due to strong injection current itself. The maximum diastolic potential after recovery was a little more negative than the control. The interesting finding was that the depolarization took place spontaneously again 60 or $90 \mathrm{~s}$ after the period of the regular spontaneous activities. The time course of the second depolarization was the same as that of the first one and terminated in $30 \mathrm{~s}$ or so. The third depolarization has not been observed as far as examined for 20 cell aggregates. 

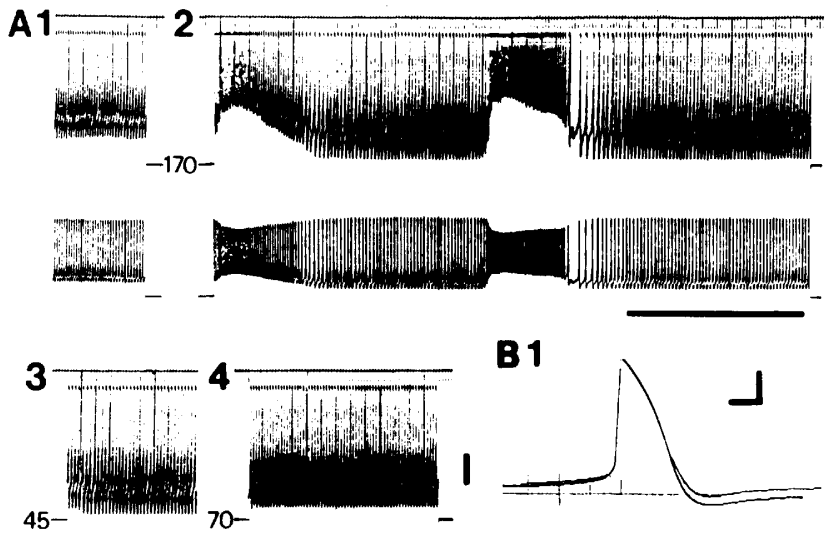

B1
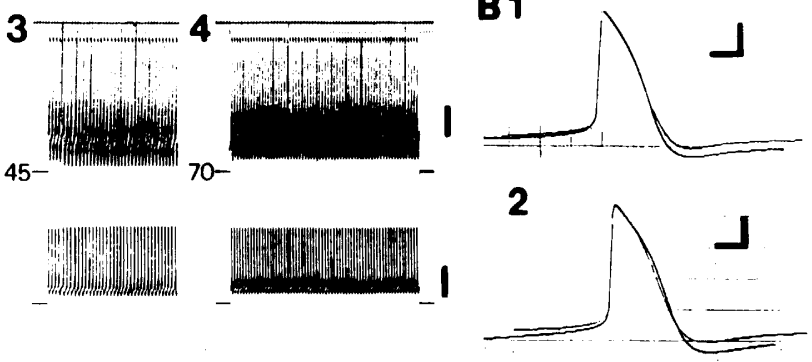

Fig. 4. A: continuous recordings of a train of action potentials (lower trace) and of diastolic potentials (upper trace). cAMP is intracellularly injected with the current of $4.5 \times 10^{-8} \mathrm{~A}$ between interrupted period of potential recording, $170 \mathrm{~s}$ between $\mathrm{A} 1$ and $\mathrm{A} 2 ; 45 \mathrm{~s}$ between $\mathrm{A} 2$ and $\mathrm{A} 3,70 \mathrm{~s}$ between $\mathrm{A} 3$ and $\mathrm{A} 4$. Vertical calibrations are 10 and $40 \mathrm{mV}$, and horizontal one is $1 \mathrm{~min}$. B1 is the superimposed CRO recording of action potentials in $\mathrm{A} 1$ and $\mathrm{A} 3$, and $\mathrm{B} 2$ is that in $\mathrm{A} 1$ and $\mathrm{A} 4$. 9-day-old embryo.

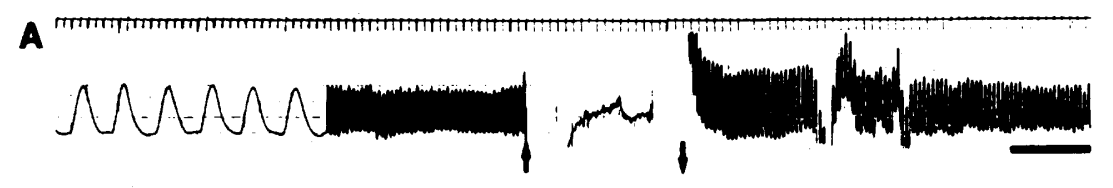

B

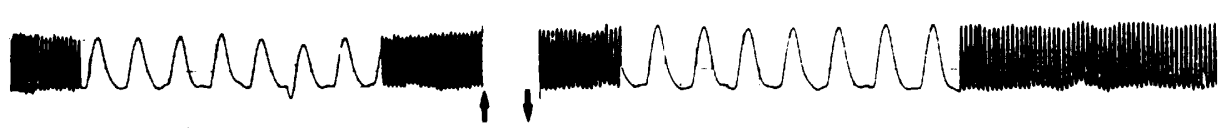

Fig. 5. Contraction of a cell aggregate. $1.0 \times 10^{-4} \mathrm{M} \mathrm{NE}$ was ejected close to the cell aggregate during the period between the two arrow marks. Two experiments from different 7-day-old embryos are shown. Horizontal calibration is $10 \mathrm{~s} .33 .5^{\circ} \mathrm{C}$.

\section{Effects of $N E, E P$, and of $c A M P$ on contraction}

The contractions were detected as the change in diameter of the cell aggregate (Toyota and Matsumura, 1989). When NE was applied briefly by ejection method, the contraction increased by $50 \%$, and after ejection was turned off, as the NE solution diffused away, it decreased back to the control (Fig. 5A). The beating rates 
Table 2. Potentiation of contraction by sympathetic agents.

\begin{tabular}{clcc}
\hline $\begin{array}{c}\text { Age } \\
(\text { day })\end{array}$ & Agents & $\begin{array}{c}\text { Conc. } \\
\left(\times 10^{-6} \mathrm{M}\right)\end{array}$ & $\begin{array}{c}\text { Contraction } \\
(\% \text { of control })\end{array}$ \\
\hline $7-8$ & NE & $0.9-1.0$ & 140 \\
& $\begin{array}{l}n=2 \\
\mathrm{NE} \\
n=3\end{array}$ & Ejection $^{1)}$ & 137 \\
7 & $\begin{array}{l}\mathrm{EP} \\
n=3\end{array}$ & Ejection & 130 \\
$7-8$ & $\begin{array}{l}\text { DBcAMP } \\
n=3 \\
\text { cAMP } \\
n=4\end{array}$ & $2-3$ & 133 \\
7,10 & $\begin{array}{l}\text { cAMP } \\
n=2\end{array}$ & & 145 \\
17 & & & 200 \\
\hline
\end{tabular}

1) In ejection method, the concentration of agents was supposed to be less than $10^{-5} \mathrm{M}$.

remained at nearly constant value of $108-114 / \mathrm{min}$ throughout the action of and recovery from NE. Another result obtained from separate cell aggregate is shown in Fig. 5B. Here, also the amplitude of contraction increased by around $30 \%$, although the beating rate remained nearly unchanged.

The contraction was increased also by EP, if applied by ejection method. The potentiation of contraction was observed by extracellular application of DBcAMP at the concentrations of the order of $10^{-6} \mathrm{M}$. The action of NE, EP, and DBcAMP on contraction is shown in Table 2.

Intracellular injection of cAMP also potentiated contraction. Figure $6 \mathrm{~A}$ shows the simultaneous recordings of the contraction and the action potential during injection of cAMP. Edge movement was recorded at the positions $70-100 \mu \mathrm{m}$ apart from the injection electrode. Contraction started to increase gradually within $1 \mathrm{~min}$ after beginning of injection and reached the steady strength in another 2 min. Meanwhile, the action potential configuration was changed only a little, as was described in the previous section. Figure $6 \mathrm{~B}$ shows another result of potentiation of contraction during cAMP injection. Here, action potentials are not recorded. The maximum potentiation attained $145 \%$ of the control. These results appear also in Table 2. Contrary to the slight effects on the rhythm and shape of the action potentials, the effects on contraction were clearly demonstrated. It is concluded that the adrenergic agents exhibited the inotropic action on ventricular cells more clearly than they did the chronotropic action.

\section{Recovery of plateau from treatment with nifedipine}

The experiments described in this section were carried out to obtain clear results of actions of sympathetic agents on the spontaneous action potential 


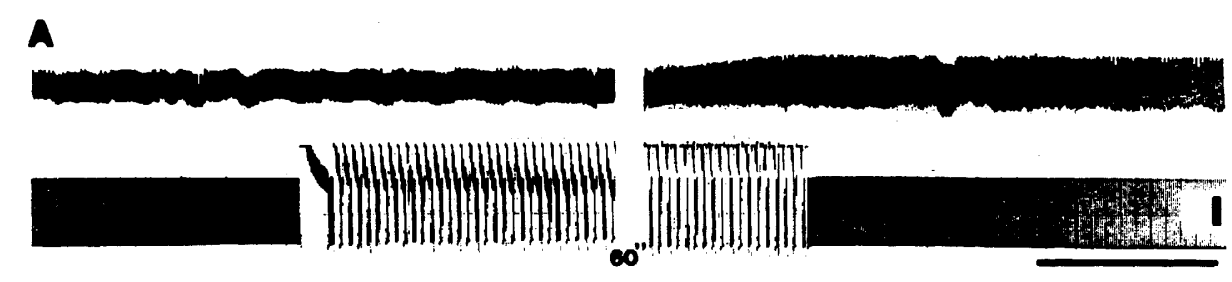

B

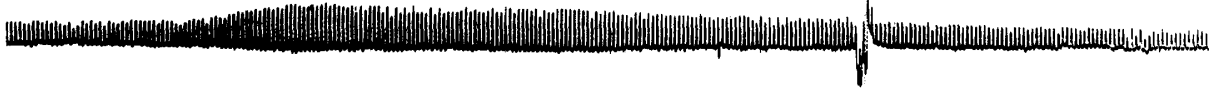

Fig. 6. A: contraction and action potential of cell aggregate. cAMP was injected with trains of the iontophoretic current pulses with $3 \times 10^{-8} \mathrm{~A}$ strength and 2-s duration interrupted by $1-\mathrm{s}$ interval. The action potential recording was disturbed during injection period. 10-day-old embryo. B: contraction of another cell aggregate. The current was passed in the same way as in A. 17-day-old embryo. Horizontal calibration is $1 \mathrm{~min}$ (for A and B) and vertical one is $40 \mathrm{mV}$ (for A only). $32^{\circ} \mathrm{C}$.

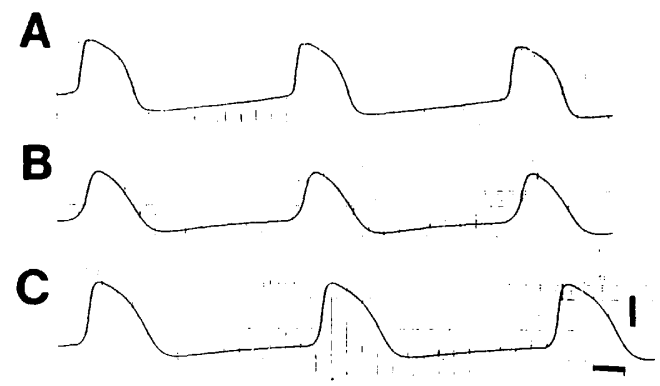

Fig. 7. A: action potentials in control medium; B: after application of $3 \times 10^{-8} \mathrm{M}$ nifedipine; and $\mathrm{C}$ : $5 \mathrm{~min}$ after further addition of $\mathrm{NE}$ at the concentration of $1.5 \times 10^{-6} \mathrm{M}$. 19-day-old embryo. Calibrations are $40 \mathrm{mV}$ and $50 \mathrm{~ms} .33 .5^{\circ} \mathrm{C}$.

parameters.

Figure 7 shows the inhibition of plateau in nifedipine solution and the recovery by NE. The plateau level was lowered after addition of $3 \times 10^{-8} \mathrm{M}$ nifedipine. The intervals of the spontaneous activities were unchanged or a little shortened at low concentrations of nifedipine. If NE was applied at the final concentration of $1.5 \times 10^{-6} \mathrm{M}$, the time course of the action potential including plateau level turned back to the one before nifedipine treatment.

The recovery of the plateau once it had been reduced by nifedipine was also observed by intracellular injection of cAMP, as is shown in Fig. 8. After injection of cAMP with the iontophoretic current of $2 \times 10^{-8} \mathrm{~A}$ for $3 \mathrm{~min}$, the shape of the action potential was nearly the same as the control (Fig. $8 \mathrm{~A}-\mathrm{C}$ ). Usually, the upper limit of the strength of injection current was $5 \times 10^{-8} \mathrm{~A}$ and stronger current pass caused the irreversible membrane depolarization, but a few cells showed resistance 

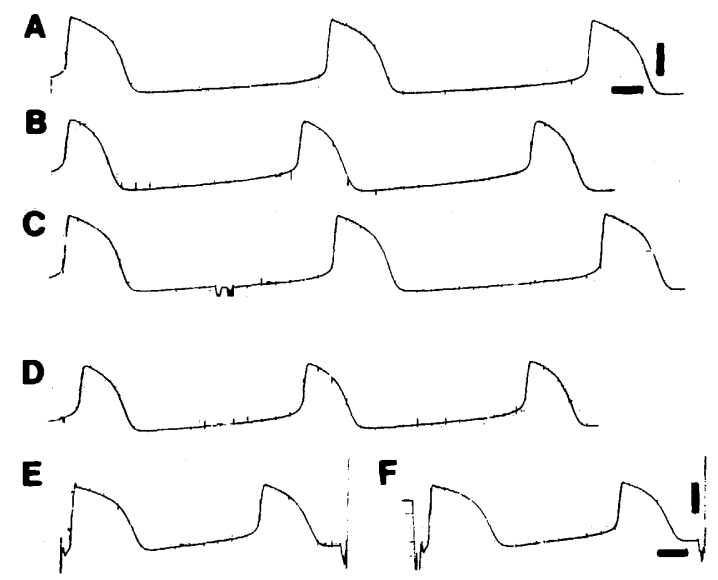

Fig. 8. A: action potentials in control medium; B: $80 \mathrm{~s}$ after application of $7 \times 10^{-8} \mathrm{M}$ nifedipine, and $\mathrm{C}$ : after iontophoretic injection of cAMP with the injecting current of $4.0 \times 10^{-8} \mathrm{~A}$ for $3 \mathrm{~min}$. 17-day-old embryo. Calibrations are $40 \mathrm{mV}$ and $50 \mathrm{~ms}$. $33.5 \mathrm{C}$. D, E, and $\mathrm{F}$ show another series of experiment. D: action potentials in $1 \times 10^{-7} \mathrm{M}$ nifedipine medium. E: after iontophoretic injection of cAMP with the injection current of $4.0 \times 10^{-7} \mathrm{~A}$ for $17 \mathrm{~s}$. F: further injection of cAMP for $20 \mathrm{~s} .17-$ day-old embryo. Calibrations are $40 \mathrm{mV}$ and $50 \mathrm{~ms} .33 .5^{\circ} \mathrm{C}$.

to current as strong as $10^{-7} \mathrm{~A}$. The plateau level recovered within $17 \mathrm{~s}$, which, of course, was much shorter than the time for weak injection current (Fig. 8D-F). The recovery of plateau by cAMP injection was observed also for the cells previously treated by verapamil.

\section{DISCUSSION}

Sperelakis and Shigenobu (1972), McDonald and Sachs (1975), and NATHAN and DeHAaN (1979) investigated the changes in electrical activities during development. Consistent with their results, the present study has shown that the 17to 19-day-old cells possessed more negative diastolic potential, larger overshoot, longer plateau, and lower rates of activity than the 7- to 9-day-old cells. In addition, our result also show that the NE sensitivity was developed in old cells.

The effects of NE on the electrical activities of cultured embryonic heart cells have been extensively investigated, but those of other catecholamines such as EP or isoproterenol have not. One of the reasons for the selective usage of NE is to study the developmental change in NE sensitivity of the cells, where sympathetic innervation is not completed (JAMES, 1970; KUPFER et al., 1982). In the present work, the effects of EP or injected cAMP were studied in addition to those of NE.

The spontaneous rate was only slightly increased by NE or EP. This result is consistent with that of SPERELAKIS and LEHMKUHL (1965). The values listed in Table 1 were obtained at the concentrations of $10^{-6}$ or $10^{-5} \mathrm{M}$ when the agent was applied 
by the steady chamber method. These concentrations were 10 times as high as that used by ERTEL et al. (1971), who showed that $10^{-7}$ or $10^{-6} \mathrm{M}$ of NE was most effective, lower or higher concentrations being less effective. In the present study, however, NE or EP at $10^{-7} \mathrm{M}$ order was found to be much less effective than at $10^{-6}$ or $10^{-5} \mathrm{M}$ in modulating action potential parameters. In the ejection method, the $\mathrm{NE}$ or EP pipette was placed $0.5-1.0 \mathrm{~mm}$ apart from the cell aggregate and the solution was ejected at the flow rate of $0.5 \mu \mathrm{l} / \mathrm{s}$. If the solution was ejected more rapidly and closer to the cells, the fluctuation of culture medium took place and it disturbed the inserted electrode within the cell and might stimulate the cell mechanically which lead to increased beating rate. Moreover, if the NE concentration was raised immediately after the injection, the cells were transiently depolarized (cf. Fig. 2), which also brought about increased rate. This depolarization at high concentration of NE can be explained as the increase in nonselective cation permeability (COLQUHOUN et al., 1981; JOSEPHSON and SPERELAKIs, 1982). Therefore, the desensitization of the cell to NE or EP was not so completely excluded as it was in the work of HERMSMEYER and ROBINSON (1977). This may be one reason why clear chronotropic action is lacking.

The NE receptor process, however, seems not to be of importance in understanding the low effectiveness, because the intracellularly injected cAMP also was not effective to exhibit the chronotropic action. According to CLAY and SHRIER (1981a,b), the decay of $\mathrm{K}_{2}{ }^{+}$outward current contributes to the generation of the pacemaker potential of the cultured embryonic cell and the progressive diminution of this current during development is the origin of the decreased spontaneous rates. This $\mathrm{K}_{2}{ }^{+}$current is now termed $i_{\mathrm{f}}$ in Purkinje fibers and can probably be so termed in embryonic ventricles, and it is activated by EP (DIFranCESCO, 1985). The low sensitivity to NE or EP can be ascribed at least in part to the immature property of $i_{\mathrm{f}}$ channel. It is also known that the adrenergic innervation starts at the later embryonic stage and is completed after birth (JAMES, 1970). The channel still has not yet fully developed in 17- to 19-day-old embryos, even though they are a little more sensitive to NE than 7- to 9-day-old ones. In sinoatrial node cells, the $\mathrm{Ca}^{2+}$ current is involved in pacemaker current (Noma et al., 1980; HaGIWARA et al., 1988). It is not certain whether $\mathrm{Ca}^{2+}$ current, in addition to $i_{\mathrm{K}_{2}}$ of CLAY and SHRIER (1981a) or $i_{\mathrm{f}}$ of DiFrANCESCO (1985), contributes to the pacemaker current of cultured ventricular cells.

All of NE, EP, DBcAMP, and injected cAMP potentiated contraction measured as the shortening of the diameter of a cell aggregate. As was discussed in the previous paper, the contraction was evaluated less quantitatively and might be underestimated. Nevertheless, the contraction was clearly increased by the sympathetic agents. The strength of contraction was inversely proportional to the beating rate (Toyota and Matsumura, 1989) and therefore, its positive chronotropic action must be independent of the change in beating rate. The potentiated contraction lasted at least $15 \mathrm{~min}$ if $\mathrm{NE}$ or EP was applied by the steady chamber method. The result means that the ventricular cells do not show the desensitization 
to these agents, so far as the inotropic action is considered. It is concluded that the principal action of the sympathetic agents on the ventricular cells is to potentiate contraction rather than to increase the spontaneous beating rate.

It was expected that, since NE, EP, or cAMP increased contraction, the inward $\mathrm{Ca}^{2+}$ current must be increased and the plateau level must be elevated by NE. This expectation will be valid although the changes in action potential parameters are only slight. The evidence is that the plateau level is well recovered from the previous treatment with nifedipine or verapamil, indicating activation of the $\mathrm{Ca}^{2+}$ current during plateau. The restoration of the plateau by EP after treatment with D600 was also reported by MCDONALD and SACHS (1975). Intracellularly injected cAMP also recovered the plateau level from nifedipine or verapamil treatment. It is already known that in adult cells cAMP prolongs the duration of and raises the level of plateau in some kinds of adult cells (TsIEN, 1973; Flitney and SingH, 1980; Trautwein et al., 1982), and increases $\mathrm{Ca}^{2+}$ current of the isolated single cell (OSTERrider et al., 1982; ReUter et al., 1983; FischmeISTER and HARTZELl, 1987), and that cAMP inhibitors reduce $\mathrm{Ca}^{2+}$ current (BKAILEY and SPERELAKIS, 1984). Although $\mathrm{Ca}^{2+}$ current is not measured directly, it is supposed that cAMP increases $\mathrm{Ca}^{2+}$ current and consequently potentiates contraction.

The interesting result after cAMP injection is that the transient shift of the maximum diastolic potential to the depolarized direction takes place repetitively. The repetitive contractions and relaxations are reported in skinned cardiac and skeletal muscle fibers at relatively low concentrations of free $\mathrm{Ca}^{2+}$ and they are increased in frequency and peak tension by cAMP (FABIATO and FABIATO, 1975, 1978). These spontaneously repetitive contractions are considered to reflect intracellular $\mathrm{Ca}$ movement between myoplasm and sarcoplasmic reticulum (SR) through $\mathrm{Ca}^{2+}$-induced $\mathrm{Ca}$ release mechanism. In the presence of cAMP, more $\mathrm{Ca}^{2+}$ is accumulated into SR and more $\mathrm{Ca}^{2+}$ is released from a more fully loaded SR. The present results on cyclic depolarization and repolarization show the similar frequency to the transient tension changes. Injection of cAMP into the cells augments Ca uptake by SR and increase Ca contents within SR. The heavily loaded SR by $\mathrm{Ca}^{2+}$ will release $\mathrm{Ca}^{2+}$ into myoplasm, and the $\mathrm{Ca}^{2+}$-induced Ca release mechanism will be facilitated. The rise of myoplasmic $\mathrm{Ca}^{2+}$ concentration activates non-selective cation channel (COLQUHOUN et al., 1981), which results in the depolarization. Increase in inward Na-outward $\mathrm{Ca}$ exchange due to a rise of $\left[\mathrm{Ca}^{2+}\right]_{\mathrm{i}}$ may be involved in this depolarization.

The fertilized eggs were kindly supplied to us by the Okayama Prefectural Poultry Experiment Station.

This study was supported in part by the Grant from the Ministry of Health and Welfare of Japan (No. 57C-1). 


\section{REFERENCES}

BKaILEy, G. and Sperelakis, N. (1984) Injection of protein kinase inhibitor into cultured heart cells blocks calcium slow channels. Am. J. Physiol., 246: H630-H634.

Clay, J. R. and SHRIER, A. (1981a) Analysis of subthreshold pace-maker currents in chick embryonic heart cells. J. Physiol. (Lond.), 312: 471-490.

Clay, J. R. and Shrier, A. (1981b) Developmental changes in subthreshold pace-maker currents in chick embryonic heart cells. J. Physiol. (Lond.), 312: 491-504.

Clusin, W. T. (1981) The mechanical activity of chick embryonic myocardial cell aggregates. J. Physiol. (Lond.), 320: 149-174 (with appendix by Hamilton, W. G. and Nelson, D. V.).

Colquhoun, D., Neher, E., Reuter, H., and Stevens, C. F. (1981) Inward current channels activated by intracellular $\mathrm{Ca}$ in cultured cardiac cells. Nature, 294: 752-754.

DiFrancesco, D. (1985) The cardiac hyperpolarizing-activated current, $i_{\mathrm{f}}$. Origins and developments. Prog. Biophys. Mol. Biol., 46: 163-183.

Ertel, R. J., Clarke, D. E., Chao, J. C., and Franke, F. R. (1971) Autonomic receptor mechanisms in embryonic chick myocardial cell cultures. J. Pharmacol. Exp. Ther., 178: $73-80$.

Fabiato, A. and Fabiato, F. (1975) Relaxing and inotropic effects of cyclic AMP on skinned cardiac cells. Nature, 253: $556-558$.

Fabiato, A. and Fabiato, F. (1978) Cyclic AMP-induced enhancement of calcium accumulation by the sarcoplasmic reticulum with no modification of sensitivity of the myofilaments to calcium in skinned fibers from a fast skeletal muscle. Biochim. Biophys. Acta, 539: 253-260.

Fischmeister, R. and Hartzell, H. C. (1987) Cyclic guanosine 3',5'-monophosphate regulates the calcium current in single cells from ventricle. J. Physiol. (Lond.), 387: 453-472.

Flitney, F. W. and SingH, J. (1980) Inotropic responses of the frog ventricle to adenosine triphosphate and related changes in endogenous cyclic nucleotides. J. Physiol. (Lond.), 304: $21-42$.

Goshima, K. (1976) Antagonistic influences of dibutyryl cyclic AMP and cyclic GMP on the beating rate of cultured mouse myocardial cells. J. Mol. Cell. Cardiol., 8: 713-725.

Hagiwara, N., Irisawa, H., and Kameyama, M. (1988) Contribution of two types of calcium currents to the pacemaker potentials of rabbit sino-atrial node cells. J. Physiol. (Lond.), 395: 233-253.

HeRMSMEYer, K. and RoBinson, R. B. (1977) High sensitivity of cultured cardiac muscle cells to autonomic agents. Am. J. Physiol., 233: C172-C179.

James, T. N. (1970) Cardiac conduction system: Fetal and postnatal development. Am. J. Cardiol., 25: 213-226.

JOSEPHSON, I. and SPERELAKIS, N. (1982) On the ionic mechanism underlying adrenergiccholinergic antagonism in ventricular muscle. J. Gen. Physiol., 79: 69-86.

KASS, R. S. and WIEGERS, S. E. (1982) The ionic basis of concentration-related effects of noradrenaline on the action potentials of calf Purkinje fibres. J. Physiol. (Lond.), 322: 541-558.

Kupfer, L. E., Robinson, R. B., and Bilezikian, J. P. (1982) Identification of $\alpha_{1}$ adrenergic receptors in cultured rat myocardial cells with a isolated $\alpha_{1}$-adrenergic antagonist $\left[{ }^{125} \mathrm{I}\right] \mathrm{IBE} 2524$. Circ. Res., 51: 250-254.

Marvin, W. J., Chittick, V. L., Rosenthal, J. K., Sandra, A., Atkins, D. L., and 
HeRmSmeyer, K. (1984) The isolated sinoatrial node cell in primary culture from the newborn rat. Circ. Res., 55: 253-260.

McDonald, T. F. and SaChs, H. G. (1975) Electrical activity in embryonic heart cell aggregates. Pflügers Arch., 354: 151-164.

Nathan, R. D. and DeHaAn, R. L. (1979) Voltage clamp analysis of embryonic heart cell aggregates. J. Gen. Physiol., 73: 175-198.

Noma, A., Kotake, H., and Irisawa, H. (1980) Slow inward current and its role mediating chronotropic effect of epinephrine in the rabbit sinoatrial node. Pflügers Arch., 388: 19.

Osterrieder, W., Brum, G., Hescheler, J., Trautwein, W., Flockerzi, V., and Hofman, F. (1982) Injection of subunits of cyclic AMP-dependent protein kinase into cardiac myocytes modulates $\mathrm{Ca}^{2+}$ current. Nature, 298: 576-578.

REUTER, H. (1974) Localization of beta adrenergic receptors, and effects of noradrenaline and cyclic nucleotides on action potentials, ionic currents and tension in mammalian cardiac muscle. J. Physiol. (Lond.), 242: 429-451.

Reuter, H., Cachelin, A. B., DePeyer, J. E., and Kokubun, S. (1983) Modulation of calcium channels in cultured cardiac cells by isoproterenol and 8-bromo-cAMP. Cold Spring Harbor Symp. Quant. Biol., 48: 193-200.

Reuter, H. and Scholtz, H. (1977) The regulation of the calcium conductance of cardiac muscle by adrenaline. J. Physiol (Lond.), 264: 49-62.

Shigenobu, K., Shibano, T., and Kasuya, Y. (1980) Negative chronotropic effect of dibutyryl cyclic AMP on the cultured chick embryonic heart cells and the prolongation of the action potential duration. J. Pharmacobiodyn., 3: 537-542.

SPerelakis, N. (1972) Electrical properties of embryonic heart cells. In: Electrical Phenomena in the Heart, ed. by DeMello, W. C., Academic Press, New York and London, pp. 1-61.

SPerelakis, N. and Lehmkuhl, D. (1965) Insensitivity of cultured chick heart cells to autonomic agents and tetrodotoxin. Am. J. Physiol., 209: 693-698.

Sperelakis, N. and Shigenobu, K. (1972) Changes in membrane properties of chick embryonic hearts during development. J. Gen. Physiol., 60: 430-453.

Toyota, H. and Matsumura, M. (1989) Relationship between contraction strength and stimulation frequency in cultured chick embryonic heart cells. Jpn. J. Physiol., 39: $87-100$.

Trautwein, W., Taniguchi, J., and Noma, A. (1982) The effect of intracellular cyclic nucleotides and calcium on the action potential and acetylcholine response of isolated cardiac cells. Pflügers Arch., 392: 307-314.

TsIEN, R. W. (1973) Adrenaline-like effects of intracellular iontophoresis of cyclic AMP in cardiac Purkinje fibres. Nature (New Biol.), 245: 120-121.

Tsien, R. W., Giles, W., and Greengard, P. (1972) Cyclic AMP mediates the effects of adrenaline on cardiac Purkinje fibres. Nature (New Biol.), 240: 181-183.

TSIEN, R. W. and WEINGaRT, R. (1976) Inotropic effect of cyclic AMP in calf ventricular muscle studied by a cut end method. J. Physiol. (Lond.), 260: 117-141.

Vogel, S. and Sperelakis, N. (1981) Induction of slow action potentials by microiontophoresis of cyclic AMP into heart cells. J. Mol. Cell. Cardiol., 13: 51-64. 